\title{
NEGOTIATION BETWEEN STAKEHOLDERS OF COMMODIFICATION: Roles and Impacts as Stakeholders in Tebing Breksi Prambanan
}

\author{
Bayu Pamungkas ${ }^{1 *}$, Warto ${ }^{2}$, Mugijatna ${ }^{3}$ \\ ${ }^{1}$ Student of Cultural Studies, Postgraduate Program, Sebelas Maret University, Indonesia \\ ${ }^{2}$ Department of Cultural Studies, Postgraduate Program, Sebelas Maret University, Indonesia \\ ${ }^{3}$ Department of Cultural Studies, Postgraduate Program, Sebelas Maret University, Indonesia
}

\section{ARTICLE INFORMATION}

Submitted : 28 February 2019

Review : 05 April 2019

Accepted : 10 May 2019

Available online: June 2019

\section{KEYWORDS}

Commodification Practice, Cultural Preservation, Tebing Breksi, Bottom-up Tourism Management, Stakeholders of Commodification

\section{CORRESPONDENCE}

*E-mail: bayupamungkas.pw@gmail.com

\section{A B S T R A C T}

Commodification practice always deals with 3 parties, which our society, government, and private institution. Considered as cultural preservation, Tebing Breksi becomes an object of commodification in Sambirejo Prambanan since 2014. Its commodification arises several conflicts among its stakeholders due to each stakeholder has their own importance and interest. Compared to other commodification practices, bottom-up tourism management is applied that making the commodification of Tebing Breksi differs to others. This research is remarkable dealing with its findings that differenciate the commodification practice between society and government or private institution. This research aims to find the implication of commodification for tourism field using bottom-up tourism management. Whereas, the main purpose of this research is to describe the negotiation between stakeholders of commodification in Tebing Breksi. The method of this research is ethnography by applying in-depth reporting. The findings of this research prove that negotiation between stakeholders of commodification is the impact of a different way of thinking as well as the group's interest in each stakeholder. Nevertheless, the changes happen among society in Tebing Breksi confirmed Tebing Breksi as an alternative tourism attraction in Prambanan.

attraction by uploading its photos in social media. Started from 2014, the trace of the mining area is acknowledged as tourism attraction due to the mining activity is prohibited. Considering Tebing Breksi that becomes one of the well-known tourist areas in Prambanan, Mr. Mujimin forms a tourism community named Pokdarwis Tlatar Seneng. On 30 May 2015, Sultan Hamengku Buwono X declares Tebing Breksi as a new tourism attraction in Yogyakarta named Tlatar Seneng and Pokdarwis Tlatar Seneng as the main tourism management. For instance, the ex-miners that are led by Mr. Kholiq Widiyanto protest the management since the village administrative does not take any role in introducing Tebing Breksi as a tourism attraction.

Stated by Miswanto \& Safaat (2018), the tourism industry is seen as a profitable activity and able to bring in great revenue. As happened in Tebing Breksi, conflicts between village 
administrative and ex-miners should be highlighted. Village administrative that has monopoly power tends to control and corner the ex-miners. The existence of Pokdarwis Tlatar Seneng also creates a situation that making ex-miners and Sambirejo villagers are alienated. On the other hand, ex-miners of Sambirejo village express their right as their role in introducing Tebing Breksi toward tourists. Their sense of belonging Tebing Breksi is the reason making them decide to take back the tourism management.

Other studies about commodification are different from the object that will be examined in the research. As on Widyastuti (2011), the practice of commodification is conducted by the government, which is the Department of Tourism in Karanganyar. On the other hand, the commodification of Tebing Breksi is completely done by the society-refer to the ex-miners. Almost similar to the current research, Bui and Lee (2015) choose contemporary heritage attractions as the main object for the research. Yet, the difference is about the finding that Bui and Lee focus on the process of turning heritage resources into tourism products. Han (2016) that also studies about the commodification of funeral ceremony in media try to find out the impacts toward socio-economic and cultural aspects to society in Korea. However this research will figure out the negotiation between village administrative and ex-miners of Sambirejo village. Therefore, this little gap among other commodification researches should be filled to complete the body of tourism and social changing study in cultural studies.

The ethnography study is applied to reveal the main roles of both parties after the commodification of Tebing Breksi. The existence of private institution is also analyzed in regards its influence on the commodification of Tebing Breksi. Yet, the focus on the negotiation for each role conducted by village administrative and ex-miners of Sambirejo village is highlighted. Finding every role of both parties is also able to determine the domination of each stakeholder. By choosing key informants such as Mr. Kholiq Widiyanto, Mr. Tri Abidin Muhammad and Mr. Mujimin is also a way to minimize the research redundancy. Moreover, by focusing the in-depth interview toward key informants, negotiation between two stakeholders can be retrieved completely.

In addition, Sujarwani, dkk (2018) claim that the empowerment of tourism focuses on community- based system. In Tebing Breksi, commodification is conducted by ex-miners as a villager of Sambirejo. The existence of Pokdarwis Tlatar Seneng that is organized by village administrative should support the ex-miners. In fact, they are trying to monopolize the tourism management and alienating the ex-miners. The research aims to find the negotiation as an impact of monopolizing the tourism management of Tebing Breksi. Therefore, finding and analyzing the roles of both parties are significant in dealing with the negotiation as well as the impacts of commodification in Tebing Breksi among society.

\section{B. METHODS}

$\mathrm{T}$ heory of commodification is applied in these cultural studies focused on tourism field. The theory is used to examine the findings that will be obtained by doing in-depth reporting. The qualitative-based research with analytic explanation is also applied by applying ethnography approach. Yin (2009) states if the finding of qualitative research has mutual interdependence between findings and process of research. Moreover, the findings are analyzed through several phases, which are data gathering, data reduction, data presentation, and conclusion as on Mohajan (2018). Whereas, it makes the findings will be broadening that making triangulation as a way to examine each finding based on experts, informants yet referring the main theory as explained by Djamal (2015: 86).

Located in Sambirejo Prambanan, the research is conducted from July 2017 until July 2018. The time frame was chosen due to the high season of tourists' trip in Tebing Breksi as informed by the management. Related to both type and source of data, data description was gathered from the informants. Purposive sampling is applied in regard to the significance of research in finding the roles of Pokdarwis Tlatar Seneng and Lowo ljo Community. Those samples are derived from the chief of Pokdarwis Tlatar Seneng that is Mr. Mujimin and members of Lowo ljo Community that are Mr. Kholiq Widiyanto and Mr. Tri Abidin Muhammad. Several instruments are used to help the researcher in gathering and finding the data, such as notebook, pocket camera, recorder, and mind-mapping. Explained by Emzir (2009: 152), ethnography research refers to human's conduct that is analyzed by the researcher not the experimental condition created by the researcher. Hence, many events and interview phases are off the record since for ethnography approach, the researcher is also considered as the instrument.

\section{RESULTS AND DISCUSSION}

A S stated by Trzmielak (2013) that commercialization means changing value based on 2 reasons, which are new technologies and knowledge of the target market. In this research, change of value also means commodification focused on tourism field. In the commodification of cultural preservation named 
Tebing Breksi, there are 3 stakeholders that have direct roles as on planning aspect, developing aspect, and fund-raising aspect. Those stakeholders are Pokdarwis Tlatar Seneng, Lowo ljo Community, and Shiva Plateau Foundation. Those stakeholders have one main purpose, which is maintaining the existence of Tebing Breksi as tourism attraction admitted both national and international tourists. Nonetheless, each stakeholder comes from a different background that leads them to different roles in the commodification of Tebing Breksi. Yet, it might trigger a conflict between those stakeholders as also explained by Yoserizal \& Yesi (2017) about conflict of interests in developing tourism attraction.

\section{Stakeholders of Commodification in Tebing Breksi}

a. Lowo ljo Community and Sambirejo Villagers

Tebing Breksi as tourism attraction is promoted by Mr. Kholiq Widiyanto, to which both ex-miner and villagers of Sambirejo village support the existence of Lowo ljo Community. The existence of this community helps every ex-miner that previously is jobless during the time of mining prohibition. Yet, several villagers in Sambirejo can also join the community by supporting them in Tebing Breksi official management. Though both ex-miner and villagers need to get used to the applied tourism management, they do not look so intimidated yet enjoying their current profession.
Joining the Lowo ljo Community, both ex-miners and villagers in Sambirejo plan and develop Tebing Breksi as a tourist attraction in 3 phases. The first phase is becoming field management collaborating with Pokdarwis Tlatar Seneng. As the main official management in Tebing Breksi, every member tries to keep the main nature and character of Tebing Breksi. It is connecting with the beginning of Tebing Breksi noticed by local tourists because of its iconic trace of the mining area. Other mining traces like in Madura and Bengkulu might also attract local tourists, yet the sediment of an ancient volcano in Tebing Breksi differ to other similar tourist attractions.

Claimed by Mr. Tri Abidin Muhamad, the design for ornaments on stairs and cliffs are originated by Mr. Kholiq Widiyanto-the chief of Lowo ljo Community. Several ideas to add a wooden bridge and a small pond are inspired when the members of Lowo ljo Community attend the seminar conducted by Yogyakarta Tourism Department. Besides getting ideas when attending the seminar, several tourists also influence the existence of supporting attraction in Tebing Breksi. In managing Tebing breksi, the official management also collaborates with a both governmental and private institution. Several events are already held, such as temple run, $4 \times 4$ and trail competition, and downhill competition. After the events are done, the tourists request the official to add such similar attraction in Tebing Breksi. Whereas, Tebing Breksi has various supportive attractions among its main limestone cliff.

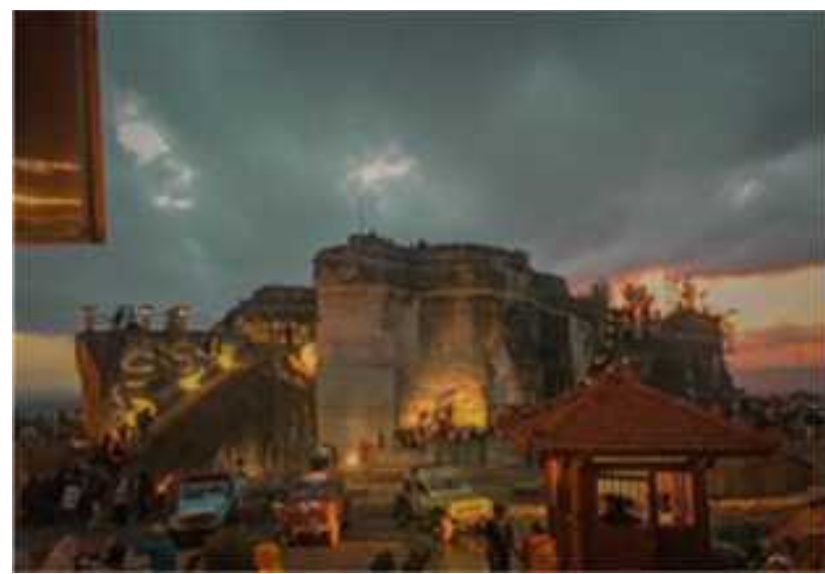

Figure 1. Main Spot in Tebing Breksi

(Documentation of Pamungkas, December 2017)

Tebing Breksi not only has the iconic stairs and ornamental artwork that become the magnetism of Tebing Breksi, but also other attractions that are considered very unique and
Instagram-able. Collaborating with the local community in Yogyakarta, several spots are developed as photo spots and outdoor activity spots. Those spots are reptile and bird area, Jeep 
$4 \times 4$ area, trail area, and many others. Despite the various supportive attractions in Tebing Breksi, official management still keeps its main icon which is the mining trace area. The official just adds and provides supportive attractions so that every kind of tourists can come and feel the glare of Tebing Breksi as an alternative tourism attraction.

The second phase, Lowo ljo Community fixes and strengthens the weakened part of Tebing Breksi. Supported by Tourism Department and Preservation Institution of Yogyakarta, official and villagers, they try to restore the environment around Tebing Breksi. Before the mining activity conducted, Tebing Breksi is actually a limestone hill like other areas. Whereas, inviting local community in Yogyakarta is a way to preserve Tebing Breksi together. The event is called Jogja Bersinergi that aiming to plant several kinds of the tree as well as exploring the surrounding area in Breksi. Considered as a preservation area, such event really empowers both community and society to preserve Tebing Breksi. Furthermore, society is willing to protect Tebing Breksi that becomes a tourist attraction from its origin.

"At that time, there was a group of youngsters that try to do vandalism in Tebing Breksi. We reminded them to enjoy the beauty of Tebing Breksi and not to destruct the existing attraction. Time by time, the tourists finally understand that they also take a role in the existence of Tebing Breksi. (Interview with Tri Abidin Muhamad in July 2017, translated by Pamungkas)"

Inconsiderably, the way in managing Tebing Breksi as a tourism attraction shows that the management tries to protect it as local preservation. The society that already joins the Lowo ljo Community really shows that they preserve the existence of Tebing Breksi as Geo-heritage area. Yet, the management realizes that the existence of Tebing Breksi support them to fulfill their daily needs. Moreover, Tebing Breksi is like the second home since most of the time spending it in Breksi. In a glance, the transformation of Tebing Breksi becomes tourism attraction also impact to the members of Lowo ljo Community.

The third phase is by doing some renewals without changing the main characteristic of Tebing Breksi. Through Lowo ljo Community, the renewal is applied to several areas around the main cliff. There is a sculpture of Arjuna and Shinta as well as Semar statue as the other sculpture. Furthermore, other areas are also developed as selfie spot that most of the tourists call it as Instagram-able spot. It indicates that most of the tourists visit Tebing Breksi since there are so many unique spots that can be taken as the background of picture for their photos on social media. Moreover, several areas are applied as a camping ground, open stage for art performance and trail track.

\section{b. Kelompok Sadar Wisata (POKDARWIS) Tlatar Seneng}

After the official announcement of Tebing Breksi as a tourism area with special attraction by Sultan Hamengku Buwono X on May 2015, Pokdarwis Tlatar Seneng is formed. This community consists of the employees of Sambirejo administrative and several members of Lowo ljo Community. Mr. Mujimin as the secretary of Sambirejo administrative becomes the chief of the Pokdarwis Tlatar Seneng. Based on the organization scheme, the position of Lowo ljo community is under the Pokdarwis Tlatar Seneng. It deals with the condition of Pokdarwis Tlatar Seneng that is officially announced by HB $X$. The current description job for this organization is to build a relationship with the central government.

In the commodification process, Mr. Mujimin deals with the design or master plan of the surrounding area in Tebing Breksi. He plans the physical construction for public areas like mosque and toilets as well as the accommodation from National Street of Piyungan - Prambanan and merchant stalls. As the secretary of Sambirejo administrative, he also utilizes the administrative treasury land for a parking lot. The role of Mr. Mujimin as the conseptor as well as the chief of Pokdarwis Tlatar Seneng is supported by both Yogyakarta Tourism Department as well as communication and transportation department. Therefore, every proposal that is made by the Pokdarwis Tlatar Seneng is always approved.

The regulation No. 9 the Year of 2015 about the administrative autonomy to utilize the area in tourism sector also supports the development of Tebing Breksi. In the commodification practice, Mr. Mujimin takes a role in building the tourism foundation, which realizing the accommodation and public areas. The concept is changing the administrative treasury land into the parking lot and merchant stalls are also considered as a great idea. On June 2017, at least 8 merchant stalls are built for villagers in Sambirejo. Several open spaces are also utilized for street peddlers due to the limit of merchant area.

Before getting the fund from the central government, Mr. Mujimin allocates the administrative fund for Tebing Breksi. He believes that Tebing Breksi can grow and become one of the iconic tourist attractions in Prambanan. Finally, his effort is supported by central government and 
several private institutions. His role as one of the stakeholders in the commodification of Tebing Breksi makes him admit that it brings true challenge. He admits that it is difficult at first since there is no one who has the basic khowledge to develop a tourism attraction. Yet, most of the villagers underestimate him since Tebing Breksi is an ex-mining area not the same like other attractions, such as ljo Temple or Gupolo Statue.

"If the Sambirejo administrative is not counted as the management of Tebing Breksi, it will take a serious impact if there is a fight over it. The ex-mining area that becomes Tebing Breksi is actually an administrative treasury land. Hence, Sambirejo administrative has right to manage it. Moreover, the aim of creating Pokdarwis Tlatar Seneng is to organize every activity held in Tebing Breksi. There is an upstream and downstream so that people should follow the stream. Yet, the field management is organized by Lowo ljo Community so that the current role of Sambirejo administrative becomes the supervisor. Once a month, a routine meeting is also conducted to discuss the current condition of Tebing Breksi. (Interview with Mujimin on November 2017, translated by Pamungkas)"

Mr. Mujimin also admits that his decision to become the supervisor of Tebing Breksi risks his position as the secretary of Sambirejo administrative. It is connected with the situation of Tebing Breksi if the management will be controlled by private institution. In fact, the development of Tebing Breksi is aimed to provide better life for villagers in Sambirejo not for private importance. Therefore, the existence of Pokdarwis Tlatar Seneng is focused in supporting Tebing Breksi.

\section{c. Shiva Plateau Foundation}

Since 2016, there is a Shiva Plateau foundation that takes a role as the public relation for any event and any $3^{\text {rd }}$ party who wants to cooperate with the management of Tebing Breksi. This foundation is organized by private who also running the business in Kaliurang named Lava Tour. Nevertheless, this organization is formed due to many $3^{\text {rd }}$ parties that want to join the hustle of Tebing Breksi as tourism attraction in Prambanan. Now, Tebing Breksi offers not only the iconic cliff as main attraction, but also several attractions from $3^{\text {rd }}$ party that will amaze the tourists.
Those $3^{\text {rd }}$ parties are actually several communities that see Tebing Breksi as promising tourism attraction. Several communities provide unsightly area that can be posted to social media by the tourists. Others provide amusement for tourists by renting trail motorcycle and mountain bike. In this community, not only community that can join Shiva Plateau Foundation but also civilians in Sambirejo village. It can be shown as many local youths from Sambirejo village start to join the membership of community that already exist in Tebing Breksi.

The role of this foundation also overcomes the dualism leadership between Pokdarwis Tlatar Seneng and Lowo ljo Community. After the official announcement of Tebing Breksi as tourism attraction by HB X, the Pokdarwis Tlatar Seneng settles its position as official management of Tebing Breksi. In fact, the role of society is very important in the development of Tebing Breksi. Furthermore, both ex-miners and Sambirejo villagers gathered and grouped on a community named Lowo ljo. Afterward, the Shiva Plateau Foundation is formed to handle financial matters for both management and routine expenditures.

For the management, this foundation relies on the private institution. Despite the management of Tebing Breksi that still developing the private institution is believed able to manage the financial matters. It is correlated with the statement of Han (2016) about third party beside government and society that has a huge role, especially in economical aspect of a tourism development. The issue in Tebing Breksi is not only investing money but also managing the financial so that it can broaden the business in tourism field.

\section{Negotiation between Stakeholders of Commodification in Tebing Breksi}

Considering the members of both Pokdarwis Tlatar Seneng and Lowo ljo Community are from Sambirejo village, it impacts toward the dualism leadership in Tebing Breksi. Yet, the role of Pokdarwis Tlatar Seneng which members are from Sambirejo village is to propose the master plan for Tebing Breksi development. Though many changes are already applied, it aims to attract every tourist coming to Tebing Breksi. Mr. Mujimin also admits that he wants to create an attraction with zero accident. It deals with the geographical condition of Tebing Breksi that mostly composed of limestone rocks. Mr. Tri Abidin Muhammad confirms that the mining activity is still conducted in minor scale aiming to beauty the mining trace. Moreover, it is a way to 
occupy ex-miners as one of the stakeholders in transforming Tebing Breksi becomes a tourism attraction.

On the other hand, all members of Lowo ljo Community have duty to organize the field management for Tebing Breksi. It also refers to the condition that most of the members are actually ex-miners and they are the most prioritized party in this commodification practice. The dualism leadership can be omitted due to the job description is clear for both stakeholders. All members of Lowo ljo organize the tourism attraction in Tebing Breksi as tour guide and merchant. In addition, the membership of Lowo ljo Community is open for all villagers in
Sambirejo so that everyone can join the management in Tebing Breksi.

As the field management, Lowo ljo Community always considers other attractions can support and settle Tebing Breksi as alternative tourism in Prambanan. Every feedback from tourists is compiled and discussed on the routine meeting between Pokdarwis Tlatar Seneng and Lowo ljo Community. As stated by Mousavi et al (2016) that industry culture in society affects in the development of tourism aspect. Whereas, most of the development ideas are either coincidentally confirmed by the tourists or members of Lowo ljo Community who do a field trip on other tourism attractions in Yogyakarta.

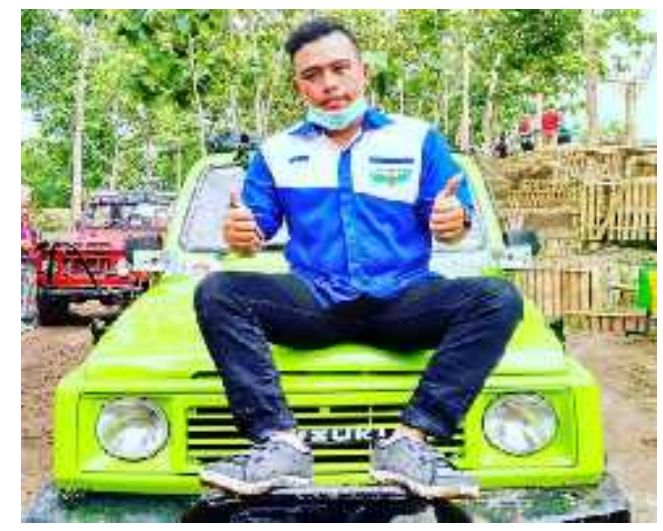

Figure 2. Member of Lowo ljo Community on Jeep Shiva Foundation (Documentation of Pamungkas, August 2017)

In brief, certain job description is made for both Pokdarwis Tlatar Seneng and Lowo ljo Community to conquer the dualism leadership in Tebing Breksi. Pokdarwis Tlatar Seneng which members are mostly from Sambirejo administrative officer deals with concept and development of Tebing Breksi. On the other hand, Lowo ljo Community deals with the official management, such as Tebing Breksi guide, parking lot official, ticketing official, and security official. Guelke (2018) also states that negotiation between possessor and occupied will deal with condition of possessor still above all. Admitted by Mr. Tri Abidin Muhammad, the negotiation between two parties is the win-win solution one.

"As long as the management refers to the society, the Sambirejo villagers will not argue even the organizational position of Lowo ljo Community is below the Pokdarwis Tlatar Seneng. We realize that living in any place must have rules and policies. We will not compromise if the management is handled by private party or government party. It refers to the condition around Prambanan temple that the society becomes the watchers.
Hence, everything is already discussed to make every party is in win-win side. (Interview with Tri Abidin Muhammad on July 2017, Translated by Pamungkas)"

Nevertheless, The role of Shiva Plateau Foundation also overcomes the dualism leadership between Pokdarwis Tlatar Seneng and Lowo ljo Community. After the official announcement of Tebing Breksi as tourism attraction by HB X, the Pokdarwis Tlatar Seneng settles its position as official management of Tebing Breksi. In fact, the role of society is very important in the development of Tebing Breksi. Furthermore, both ex-miners and Sambirejo villagers gathered and grouped on a community named Lowo ljo.

Afterward, the Shiva Plateau Foundation is formed to help in handling the financial matters for both management and routine expenditures. For the management, Shiva Plateau Foundation relies on the private institution. Despite the management of Tebing Breksi that still developing, the private institution is believed able to manage the financial matters. It is correlated with the statement of Han (2016) about third party beside 
government and society that has a huge role, especially in economical aspect of a tourism development-in Tebing Breksi case not only investing money but also managing the financial.

\section{Impacts of Commodification Among Society in Sambirejo Village}

Based on the findings, commodification using bottom-up management for tourism gives many impacts as on the social changing, economical changing, and cultural changing for society in Sambirejo village. The changing cannot be observed directly because it takes time to observe a society that constructs new habit. In addition, Liedwij (2013:11) see that a transformation on function and kind of tourism making tourism is not separated to lifestyle. Hence, the commodification really impacts to the life of society as the aplicants.

\section{a. Impacts on Social Aspect}

Explained by Waskito (2013), the society nearby tourism area is impacted in socio-economy in regard the development of Tebing Breksi as tourism attraction. One of the impacted aspects in commodification of Tebing
Breksi is on language selection. It grants the data on the changing of the social aspect on lexical disorder. The society tends to mix Javanese language with Indonesian language in the daily conversation. This changing is merely happened due to most of the tourists that come to Tebing Breksi using Bahasa Indonesia. Several common words that are often combined with Bahasa Indonesia phrase like injih and mawon. This phenomenon shows that society is accustomed to speak in Javanese, yet their current culture demands them to speak in Bahasa Indonesia.

Either society in Sambirejo Village or both members of Lowo ljo Community and Pokdarwis Tlatar Seneng also do not take any resistance with the construction in Tebing Breksi. Furthermore, they support the construction by doing Gotong Royong as part of belonging the Tebing Breksi that already change their life better. Even global culture constantly changes the life of society in Sambirejo village, several local wisdoms still exist. Hence, even tourism is product of global culture, local culture can withstand among global influences. It can be seen in the picture as follow.

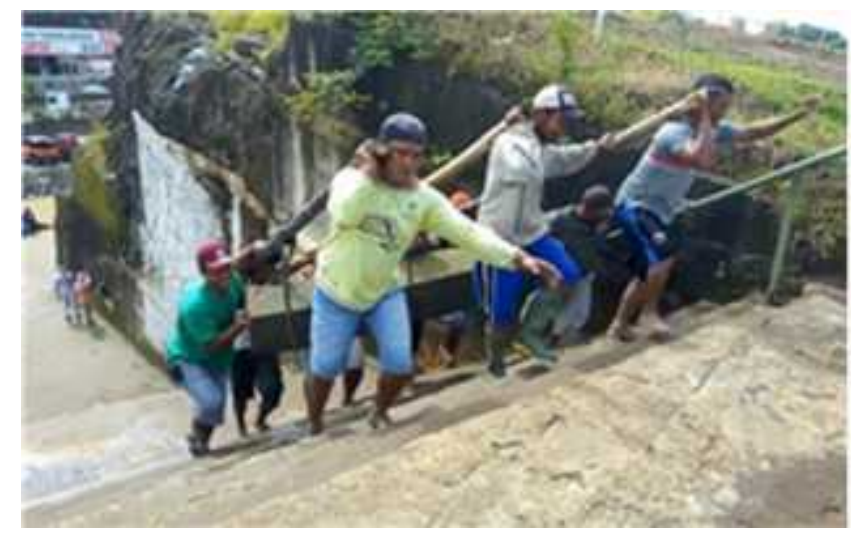

Figure 3. Gotong Royong in Tebing Breksi by Sambirejo Villagers (Documentation of Pamungkas, Januari 2018)

In addition, all members in Tebing Breksi management firmly protect the tourism area from any bad impacts. All members are not allowed to drink any alcohol during their shifting when working in Tebing Breksi area. It can be concluded that the image of society in Sambirejo village also represents the image of Tebing Breksi. The way in managing Tebing Breksi as a tourism attraction shows that the management try to protect it as local preservation. In addition, they also restrict any vandalism and bad behavior around the tourism area.

\begin{abstract}
"There was several youngsters doing vandalism in Tebing Breksi. We reminded them to enjoy Tebing Breksi and not to destruct anything. Now, tourists realize their role is important for the existence of Tebing Breksi. (Interview with Tri Abidin Muhamad on July 2017, translated by Pamungkas)"
\end{abstract}

\section{b. Impacts on Economical Aspects}

On the economical aspect, the society changes their main profession as a miner or a day-laborer become a tour guide or a merchant. As the commodification of Tebing Breksi is 
conducted by exploiting the area of mining trace, it deals with the profession to those who work in the area. Explained by Tri Abidin Muhammad, most all members of Lowo ljo Community are former miner or former day-laborer. After the regulation in prohibiting and preserving the area of Tebing Breksi, all of the miners are laid-off.

The changing in economical aspect is started from the year of 2014 where many local tourists come to visit Tebing Breksi. That situation is realized by the ex-miners and day-laborers as starting point to change the mining trace as tourism attraction. Finally, almost all ex-miners and day-laborers change their profession become tour guide or merchant in Tebing Breksi area. The evolvement of Tebing Breksi is completely influencing other civilians in Sambirejo village to join the community in managing the tourism area.

\section{c. Impacts on Cultural Aspect}

Despite the changing in social aspect and economical aspect, the commodification of Tebing Breksi also impacts on the cultural aspect. As shown in the figure 1.2., it shows that one of the members of Lowo ljo Community tend to dress in modern way as now they become a tourist-guide or a merchant. This tendency starts to appear since many tourists visit Tebing Breksi, even international tourists. Every member of Lowo ljo Community and merchants wear proper clothes, yet in a special occasion wearing a uniform. They start to wear sneakers or boots, waist bag, and fashionable and branded stuffs.

Admitted by Tri Susanto, before the commodification of Tebing Breksi, most of them only wear short pants and sandals. The situation is completely different now since everyone who joins the practice of commodification changes their style. Moreover, current profession as tour guide or merchant is completely different compared to previous profession as miner or day-laborer. Tri Susanto also states that his current job is completely different compared to his former job.

"We was so free before. We can wear anything that we want. Wearing t-shirt, sandals or even barefoot. At that time, we just go to limestone mining area. No one cares about our appearance. Now, we work as tour guide. The tourists are our guest and we should welcome them well. One of several ways is by showing good appearance." (Interview with Bapak Tri Susanto on December 2017, translated by Pamungkas)

In addition, the society also starts to acknowledge both traditional and modern events that are conducted in Tebing Breksi area. Usually, the most attractive shows in Sambirejo area are Dangdut and Jathilan. Now, people in Sambirejo village start to enjoy the performance of traditional dance and modern local band show. Whereas, many regional and national events conducted such as Soundsations, Temple Run 2017, Indonesian Down Hill, and many others since the official announcement as tourism attraction. Mr. Mujimin admits that the villagers of Sambirejo always come to visit Tebing Breksi when a show is conducted especially at night. Despite the nuance is very crowd, people in village always curious about something new happen nearby their living society. He also believes that the main reason that making anyone come to visit Tebing Breksi because of the uniqueness and iconic attraction of Tebing Breksi compared to other tourism attractions.

\section{d. Post-Commodification of Tebing Breksi}

The most important thing on the commodification phenomenon in Tebing Breksi is that bad impacts are less than good impacts. Compared to other studies about commodification phenomena, it always tells a story about society's resistancy. Yet, other commodification phenomena looks making the society as the watchers rather than applicants. Most of those phenomena happened because of the domination of either governmental or private institutions. On the other hand, the phenomenon in Tebing Breksi from bottom-up commodification raises more good impacts in several sectors. Even bad impacts are still exist, it can be covered up due to the society in Sambirejo village still struggles in developing tourism in Tebing Breksi. Mr. Mujimin claims that commodification started by society is better even he is also admitting that further guidance in tourism development is still needed.

Kaewkhunok (2018) says about the 3 most important findings on a commodification study refer to existence, elegance, and relevance between attraction and society. As commodification of Tebing Breksi gives various impacts toward society, it deals with the current self-actualization of society. The way of thinking, the lifestyle, the habit, and the behavior are simultaneously changed due to concept of tourism as global culture. Pallavicini (2017) adds that the existence of attraction is very important to expand the industry of tourism that also becomes the main foundation. She also adds that without attraction, there will be no tourism. Briefly, the relevance between tourism that creates a new stream is upright toward society as it also creates culture. It confirms Tebing Breksi as tourism attraction that should be visited among others in Prambanan. 


\section{CONCLUSION}

$\mathrm{n}$ conclusion, the commodification practice happened in Tebing Breksi impacts on the dualism leadership for management. After the negotiation between two parties, finally each party takes different role so that it can reduce the conflict. For Pokdarwis Tlatar Seneng, this organization deals with the concept for Tebing Breksi development. On the other hand, Lowo ljo Community becomes the field management due to most of the members are ex-miners in Tebing Breksi. This decision is considered as the win-win solution for both parties. Moreover, each role can confirm Tebing Breksi become one of the alternative tourism attraction in Prambanan.

The commodification of Tebing Breksi also impacts on three aspects, which are social, economic, and cultural. On the social aspect, the society tends to use Bahasa Indonesia in the daily conversation and more accepting the technology development. On the economical aspect, the society changes their main profession as a miner or a day-laborer become a tourism-guide or a merchant. On the cultural aspect, the society tends to dress in modern way, starting to acknowledge both traditional and modern arts as well as changing their perspective as rural people.

Those impacts of commodification in Tebing Breksi are just short-term impacts since this study is conducted more or less 1 year. The resistance might not be observed due to Tebing Breksi just start to be acknowledged by tourists. As a new alternative tourism attraction, Tebing Breksi is often visited by local tourists especially from east java, central java and west java. Despite the commodification practice effects on those short-term impacts as tourism attraction, commodification must impact other factors. Therefore, further study is needed to broaden the body of tourism and social change or other related studies.

\section{E. ACKNOWLEDGEMENT}

thank to those who had helped me in the process of making this journal published, especially my lecturers Prof. Dr. Warto, M.Hum and Prof. Drs. Mugijatna, M.Si., Ph.D. as my supervisors.

\section{REFERENCES}

AWH. (2017). "Taman Tebing Breksi Destinasi Favorit”. Kedaulatan Rakyat, 27 Mei 2017.

BPCB Gorontalo. (2014). "Undang-undang No. 11 Tahun 2010 tentang Cagar Budaya". Retrieved from https://kebudayaan.kemdikbud.go.id on June 2018.

BPHN. (2015). "Undang-undang Republik Indonesia No. 9 Tahun 2015 tentang Pemerintah Daerah". Retrieved from https://bphn.go.id/data/15uu009/ on June 2018

Bui, H.T., \& Lee, T.J. (2015). "Comodification and Politicization of Heritage: Implications for Heritage Tourism at The Imperial Citadel of Thang Long, Hanoi (Vietnam)". ASEAS - Austrian Journal of South-East Asian Studies, VOL. 8 (2), 187-202. Austria.

Djamal, M. (2015). Paradigma Penelitian Kualitatif. Yogyakarta: Pustaka Pelajar.

Emzir. (2009). Metodologi Penelitian Pendidikan: Kuantitatif dan Kualitatifi. Jakarta: PT Raja Grafindo Persada.

Guelke, Karoline. (2018). Tourism in an Andean Community: Negotiating Inequality, Gender, and Change. USA: University of Victoria.

Han, G.S. (2016). "Funeral Capitalism: Commodification and Digital Marketing of Funeral Services in Contemporary Korea". Korean Studies, Vol. 40, 2016: pp. 58-77. Seoul, South Korea.

Kaewkhunok, Suppawit. (2018). "The Commodification of Culture: Bhutan's Tourism in Globalisation Context." Thammasat Review, Vol 21. 2018: pp. 152-164. India.

Liedwij, B. V. (2013). Community-Based Tourism: Local Participation and Perceived Impacts. Netherlands: Radbound University Nijmegen.

Mohajan, Haradhan. (2018). "Qualitative Research Methodology in Social Sciences and Related Subjects". Journal of Economic Development, Environment and People. Vol.7, pp. 23-48. Bangladesh.

Miswanto, \& Safaat, M. (2018). "Dampak Pembangunan Industri Pariwisata Terhadap Alih Fungsi Lahan". Jurnal Antropologi: Isu-isu Sosial Budaya. Vol. 20 (1): 445-55. Padang.

Mousavi, S.S. et al. (2016). "Defining Cultural Tourism". In International Conference on Civil, Architecture and Sustainable Development (CASD-2016). Dec. 1-2, 2016. London (UK). 
Pallavicini, J.A.C. (2017). "Factors Influencing Tourism Destination Attractiveness: The Case of Malaga." In International Conference on Planning, Environment, Territories (PLANET EUROPE). June $14^{\text {th }}, 2017$. Malaga.

Sujarwani, dkk. (2018). "Pemberdayaan Masyarakat Komunitas Adat terpencil (KAT) Oleh Pemerintah Kabupaten Lingga, Kepulauan Riau". Jurnal Antropologi: Isu-isu Sosial Budaya. Vol. 20 (1): 17-31. Padang.

Trzmielak, D, M. (2013). Commercialization of Research Results: Cooperation Between Science and Business. Lodz : Univeristy of Lodz.

Waskito, A. (2013). "Dampak Investasi Asing terhadap Kehidupan Sosial Ekonomi Masyarakat di Kepulauan Derawan". eJournal Hubungan Internasional, no. 1(1), hlm. 15-24. Samarinda.

Widyastuti, D. A. R. (2011). "Komodifikasi Upacara dan Religi dalam Pemasaran Pariwisata". Jurnal Komunikasi, no. 2 (1). hlm. 197-208. Yogyakarta.

Yin, R.K. (2009). Qualitative Research : Case Study Research (4 $4^{\text {th }}$ Ed.). London, UK: Sage Publishing. Yoserizal, \& Yesi. (2017). "Conflict of Interest Among Stakheolders in Tesso Nilo National Park (TNNP)". Jurnal Antropologi: Isu-isu Sosial Budaya. Vol. 19(2): 101-107. Padang. 